\title{
Special Courts as Nigerian Criminal Justice Response to the Plight of Awaiting Trial Inmates in Ebonyi State, Nigeria
}

\author{
Chukwuemeka Dominic Onyejegbu ${ }^{1}$, Emeka M. Onwuama ${ }^{2}$, ONAH, Celestine Chijioke ${ }^{1}$, \\ John Thompson Okpa ${ }^{3}$ and Benjamin Okorie Ajah ${ }^{1, *}$
}

\author{
${ }^{1}$ Social Sciences Unit, School of General Studies, University of Nigeria, Enugu Campus, Nigeria \\ ${ }^{2}$ Humanities Unit, School of General Studies, University of Nigeria, Enugu Campus, Nigeria \\ ${ }^{3}$ Department of Sociology, Faculty of Social Sciences, University of Calabar, Nigeria
}

\begin{abstract}
This study looks at how using special courts can provide succor to the plight of awaiting trial inmates in Ebonyi state, Nigeria. The study adopted quantitative and qualitative research methods, with a sample of 1,498 respondents comprising 617 police officers, 623 awaiting-trial inmates, 113 court staff, and 145 prison officers drawn from Ebonyi State. Purposive and Multi-stage sampling techniques were used to reach the respondents. The quantitative data was descriptively analyzed using percentages and charts, while a thematic method of analysis was employed in the qualitative data. The findings revealed that, while there has been an uptick in awaiting trial problems, there is no meaningful provision to address them, despite the existence of provisions within the Nigerian legal framework. The article calls for the creation of special courts that are equipped to address peculiar crime cases in a more effective and faster manner. These courts are better poised to address the peculiarities of special cases and pass better and faster judgments.
\end{abstract}

Keywords: Awaiting trials, Dispensation of justice, Plight, Special courts, Succor.

\section{INTRODUCTION}

The Nigerian criminal justice system (NCJS) is rooted in the colonial past of the country and public perception of the justice system is largely negative (Ayade, 2010; Barchue, 2012; Ajah, 2018; Ajah \& Okpa, 2019). Amnesty International (Al) (2008:2) classified the Nigerian criminal justice system as a "conveyor belt of injustice, from beginning to end". Alemika and Alemika (2005) asserted that there is minimal concern for the rights of the suspects at all levels of the system from the police to the prisons. This means that the various components within the criminal justice system have failed in their duties as accused persons are supposed to get speedy trials (Ukwayi, \& Okpa, 2017). According to Emmanuel (2016); and Ajah (2018), prisons are filled with people whose human rights are systematically violated. Approximately 65 percent of the inmates are awaiting trials, most of whom have been waiting to be tried for between two to fifteen years. Of the 57,121 prisoners reported on the website of Nigeria's Prisons Service, 43, 8842 (68\%) wait for uncertain trials (Agbesi, 2016; Opafunso \& Adepoju, 2016). Over $80 \%$ of congested prisons in urban areas house more awaiting-trial inmates than actual convicts (Ajah, Uwakwe, Nwokeoma, Ugwuoke \&, Nnamani, 2020; Omale, 2013).

*Address correspondence to this author at the Social Sciences Unit, School of General Studies, University of Nigeria, Enugu Campus, Nigeria;

Tel: +2347037004611; E-mail: okorie.ajah@unn.edu.ng
Considering Ebonyi State, many palpable elements characterize the processes of justice in the state; such elements include stringent bail conditions (Adegbami \& Uche, 2015), non-utilization of non-custodial measures (Ugwuoke, 2010), and absence of special courts. The existence or nonexistence of these elements stifles efficiency in the criminal justice system in the State. The implication is that Ebonyi State criminal justice system has failed to achieve a systemic equilibrium and success in its goals. There are two prisons in Ebonyi state, Afikpo and Abakaliki Prisons. While Afikpo and Abakaliki Prisons were built for inmate populations of 86 and 385 respectively, they currently house 215 and 1128 inmates respectively. Of this number, $75 \%$ of inmates in Abakaliki prison are awaiting trial and $78.1 \%$ await trials in Afikpo prison (Nigerian Prisons Record, 2017).

Similarly, some cases are often delicate and require special attention more than regular courts can provide. And when handled by regular courts, they linger more than necessary (Ajah, Uwakwe, Nwokeoma, Ugwuoke \&, Nnamani, 2020; Nnam, Effiong, lloma, Terfa \& Ajah, 2021). Special courts are required for such special cases and the inadequate availability of special courts in Ebonyi State has incredibly contributed to the teeming population of awaiting-trial inmates in the state. The benefits of special courts are immense and include special understandings that often culminate in the adoption of noncustodial measures for criminal offenders. Application of alternative measures instead 
of remanding crime offenders in prisons or police custody has proven effective in western countries and helped reduce congestion in prisons (Agbesi, 2016; Opafunso \& Adepoju, 2016). The absence of these measures and facilities in Ebonyi State has also contributed to the congestion of prison facilities in the state.

Although much progress has been made over the years in understanding the nature and dynamics of awaiting trial problems (See, for example, Ugwuoke, Ajah \& Onyejegbu, 2020; Abdulkarim, 2012; Agbesi, 2016; Akinseye, 2009; Araromi, 2015; Nnam, Ajah, Arua, Okechukwu and Okorie, 2019; Ajah, Ajah \& Obasi, 2020; Eze, Ajah, Nwonovo \& Atama, 2021; Anthony, Obasi, Obi, Ajah, Okpan Onyejegbu, Obiwulu \& Onwuama, 2021), most of the literature are still based on intuitive narrations on the causes and implications of awaiting trial problems. Robust and empirical studies on how special courts could address awaiting trial problems in Nigeria are lacking. This gap poses serious limitations not only to efforts in designing and carrying out truly scientific and policy-based studies on the criminal justice system but also to the survival of justice, law, and order in Nigeria. This lies the strength of this study which takes the onerous approach to understand why awaiting-trial problems persist in Nigeria despite policies made to control it.

\section{METHODOLOGY}

\section{Design and Participants}

Cross-sectional research design was adopted in the study because of its appropriateness in accurately gathering relevant data within a limited time frame
(Eze, Obi \& Ajah, 2020; Areh, Onwuama \& Ajah, 2020). Similarly, 4,032 was the target population for the study but a sample of 1,551 was computed through Yamane's (1967) method of sample size determination, with a $95 \%$ confidence level and level of maximum variability $(P=0.02)$. However, 1,498 respondents were used after data collation, cleaning, and analysis.

We explained in detail the meaning and roles of special courts in the CJS to the participants and how they could be used to lubricate and enhance the efficiency of the NCJS.

\section{Data Collection, Analysis, and Ethical Clearance}

The structured questionnaire (quantitative data) and unstructured In-Depth Interview (qualitative data) were the instruments for data collection. Utilizing descriptive statistics, the results of quantitative data were analyzed using tables, frequencies, and charts. On a similar footing, a manual thematic method was used to analyze the qualitative data. Ethical clearance was obtained from the ethical committee of the University of Nigeria, Nsukka Teaching Hospital. And the participation in the study was risk-free, anonymous, and based on the informed consent of the respondents.

\section{RESULTS AND DISCUSSION}

The chart shows that $5.3 \%$ of the respondents had spent $4-6 y e a r s$ in custody awaiting trial, $24.8 \%$ had spent $7-9 y r s, 42.5 \%$ of the ATIs had spent between 10 12 years in custody, $15.9 \%$ of the ATls had spent 13 5years in custody, and $11.5 \%$ of the ATls had spent more than 15years in custody - all awaiting trial. This is an indication that the highest percentage $(42.5 \%)$ of the

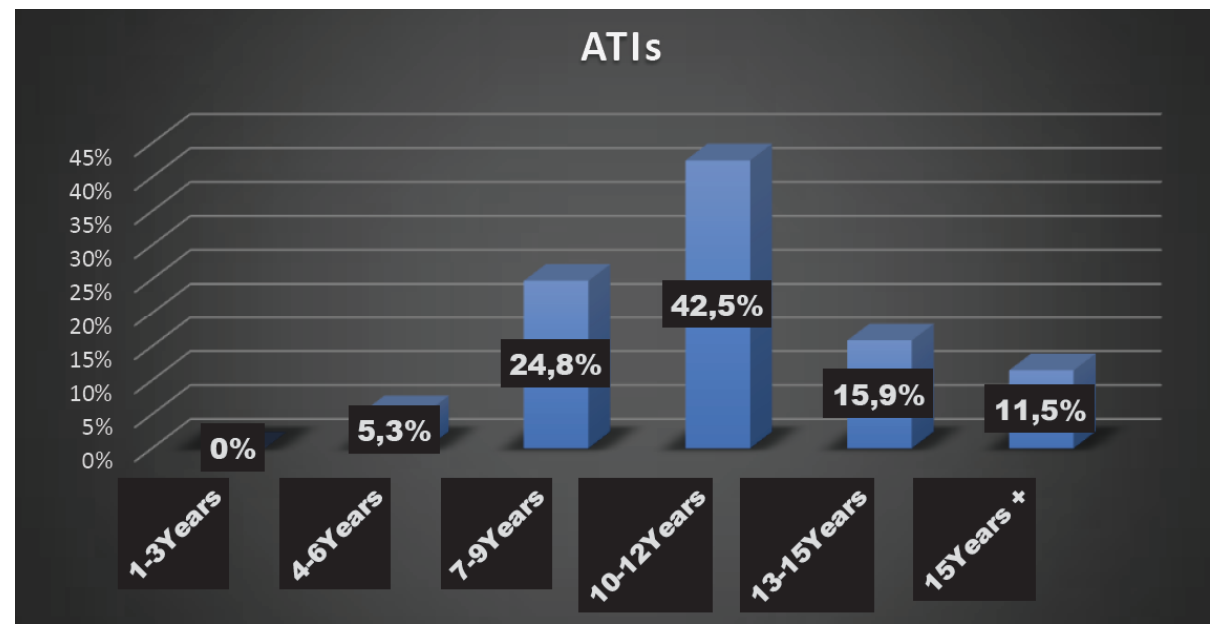

Figure 1: A bar chart showing length of time spent by ATI's awaiting trial.

Source: (Field Survey, 2019) (Ajah et al., 2020). 
Table 1: Respondents' Opinions on the Existence of Special Courts in the Nigerian Criminal Justice System (NCJS) as a Framework that could Address the Challenges Facing the ATIs

\begin{tabular}{|c|c|c|}
\hline Response & Frequency & Percentage \\
\hline \multicolumn{3}{|c|}{ Awaiting-trial inmates' opinions on the existence of special courts } \\
\hline Yes & 623 & $100 \%$ \\
\hline No & 0 & $0 \%$ \\
\hline Total & 623 & $100 \%$ \\
\hline \multicolumn{3}{|c|}{ Police officers' opinions on the existence of special courts } \\
\hline Yes & 0 & $0 \%$ \\
\hline No & 617 & $100 \%$ \\
\hline Total & 617 & $100 \%$ \\
\hline \multicolumn{3}{|c|}{ Prison officers' opinions on the existence of special courts } \\
\hline Yes & 0 & $0 \%$ \\
\hline No & 145 & $100 \%$ \\
\hline Total & 145 & $100 \%$ \\
\hline \multicolumn{3}{|c|}{ Court officials' opinions on the existence of special courts } \\
\hline Yes & 0 & $0 \%$ \\
\hline No & 113 & $100 \%$ \\
\hline Total & 113 & $100 \%$ \\
\hline
\end{tabular}

Source: Field Survey, 2019.

awaiting-trials inmates had spent between 10-12years in custody. The above findings agree with the assertions of Chukwujindu, Akintude, and Alaba (2016); Emeka, Achu, Dien and Uyang (2016); Okunola and Dinne (2016); Ajah and Ugwuoke (2018) when they opined that ATIs are victims of fundamental human right abuse as Nigerian prisons guarantee no prompt trial. Okunola and Dinne (2016) further observed that most ATls in Agodi prison in Ibadan had spent 5-10 or more awaiting trial for offences such as armed robbery, homicide, peddling in hard drugs, and even for petty offences. This shows that the delays in the criminal justice systems especially as it concerns the ATIs are not peculiar to Ebonyi prison, it is equally prevalent in other states in Nigeria like Oyo as observed by Okunola and Dinne (2016).

All the respondents were asked whether they are aware of special courts as a framework that could address the challenges facing awaiting trial inmates in Nigerian prisons. Their responses are shown in Table 2 below.

Table 1 showed respondents' opinions on the existence of special courts as a framework that could address the challenges facing the awaiting trial inmates in the NCJS. The result confirmed that all the respondents (100\%) maintained that there are no such courts in the criminal justice system of Nigeria.

The above finding is in line with the findings derived from qualitative data as one of the CJS agents interviewed shared his view:

It is very true there are no special courts in our justice system and lack of it delays criminal trials in Nigeria which has led to the congestion of courts and prisons. But if we have such a special court it will help speed up cases already congested in existing courts. If cases are addressed as quickly as possible the prison congestion will reduce. There will be efficient and effective management of the suspects. When the suspects are few in prison because a criminal trial will be quick it will also enhance proper classifications of prisoners for their treatment and the breeding of criminal-minded prisons will be reduced.

\section{Male/Prison Staff/14 Years in Service as a Prison Warden/Abakiliki Prison/July 2019}

Another respondent had this to say about the absence of special court and delays in criminal trials: 
Because of the absence of special courts, the regular courts are inundated with cases. Noting that there are fewer courts, magistrates, and judges in the country compared to the cases - this imbalance eventually results in delays in criminal trials and proceedings.

\section{Male Magistrate/6 Years Experience as a Legal Practitioner/Afikpo /August 2019}

From the respondents' assertions, it is obvious that the lack of special courts delays criminal trials in Nigeria. This has also led to congestions in courts and prisons as lack of personnel and spaces for speedy criminal trials inhibit fast criminal proceedings. This lack of special courts has also led to inefficient management of suspects. It has in turn led to poor classifications of prisoners which also affects the treatment of suspects and further causes recidivism amongst prison inmates. The above finding is in contradiction with the assertions of Halima (2016); Ibe (2016); Inyang and Awakessien (2014); Nnochiri (2011); Olusegun (2012); Omaka (2010); Opafunso and Adepoju (2016); Nnamani, Ilo, Onyejegbu, Ajah, Onwuama, Obiwulu and Nzeakor (2021) who asserted that justice is delayed because it is common to find trials being held up for days, weeks and even months because of inadequate courts to try accused persons. David (2017); Ajah and Onyejebu (2019); Ajah Dinne and Salami (2020) opined that the situation could be worse where the victim of crime or witness is deaf and dumb and no one is trained to interpret the specialized sign language to the court (David, 2017; Ajah \& Onyejebu, 2019; Ajah, Dinne \& Salami, 2020).

To ascertain whether the creation of special courts could help in fast-tracking criminal trials, the opinions of the respondents were sought and their responses are presented in Tables $\mathbf{2}$ and $\mathbf{3}$ below.

Table 2 below presents ATIs' opinions on whether creating special courts would fast-track criminal trials. The data shows that $18.1 \%$ of the ATls said that creating such courts is most necessary to fast track criminal trials, $50.2 \%$ of the ATls said it is necessary, $26.8 \%$ of the ATls said it is somewhat necessary to fast track criminal trials, $2.7 \%$ of the ATls said it is unnecessary while only $2.1 \%$ of the ATIs said it is least necessary to fast track criminal trials. This is an indication that the majority $(50.2 \%)$ of the ATIs said creating special courts is necessary to fast-track criminal trials. This could be as a result of incessant delays by the regular court in finalizing some cases

Table 2: ATIs' Opinions on Whether Creating Special Court could Fast Track Criminal Trials

\begin{tabular}{|c|c|c|}
\hline Creation of special courts & Frequency & Percentage \\
\hline \hline Most necessary & 113 & $18.1 \%$ \\
\hline Necessary & 313 & $50.2 \%$ \\
\hline Somewhat necessary & 167 & $26.8 \%$ \\
\hline Unnecessary & 17 & $2.7 \%$ \\
\hline Least necessary & 13 & $2.1 \%$ \\
\hline Total & $\mathbf{6 2 3}$ & $\mathbf{1 0 0 \%}$ \\
\hline
\end{tabular}

Source: Field Survey, 2019.

Table 3: CJS Agents Response on Whether Creating Special Courts could Help Address Awaiting Trial Problems

\begin{tabular}{|c|c|c|c|}
\hline \multicolumn{4}{|c|}{ Criminal Justice Systems Agents } \\
\hline Opinions & Police & Prisons & $36(31.9 \%)$ \\
\hline \hline Most necessary & $229(37.1 \%)$ & $51(35.2 \%)$ & $58(51.3 \%)$ \\
\hline Necessary & $263(42.6 \%)$ & $91(62.7 \%)$ & $19(16.8 \%)$ \\
\hline Somewhat necessary & $45(7.3 \%)$ & $0(0 \%)$ & $0(0 \%)$ \\
\hline Unnecessary & $49(7.9 \%)$ & $3(2.1 \%)$ & $0(0 \%)$ \\
\hline Least necessary & $31(5 \%)$ & $0(0 \%)$ & $\mathbf{1 1 3}(\mathbf{1 0 0} \%)$ \\
\hline Total & $\mathbf{6 1 7 ( 1 0 0 \% )}$ & $\mathbf{1 4 5 ( 1 0 0 \% )}$ & \\
\hline
\end{tabular}

Source: Field Survey, 2019 
over a long period and results in ATIs staying longer in custody.

Table 3 presents agents of CJN responses on the assertion that creating special courts will go a long way to curtail the challenges of ATIs in criminal trials. The result shows that amongst the police, a higher percentage $(42.6 \%)$ agreed that it is necessary to create special courts. Amongst the prison officials, the majority $(62.7 \%)$ stated that it is necessary to create special courts. Amongst court officials, the majority $(51.3 \%)$ stated that it is necessary to create special courts. This indicates that all the agents of the criminal justice system agreed that creating special courts will greatly ameliorate the plight of awaiting-trial inmates. As established above, continuous adjournment of cases is one of the problems of awaiting-trial inmates especially as it concerns criminal proceedings. The creation of special courts will not only help to curtail the incessant adjournment of cases but also enhance the speedy conclusion of criminal trials.

\section{CONCLUSION}

Every crime breaches section(s) of the constitution or agreed rules - but all crimes are not exactly equal. A crime of verbal assault cannot be equated to murder or rape of minors. This is not only because of moral perceptions but also because of the level of unpleasant impacts experienced by victims. In addition to the difference in intensity of these crimes, their nature also varies. Some demand certain peculiarities or resources to be successfully judged by a court while others demand little peculiarities or nothing. Juxtaposing all these crime cases in one court regardless of the differences and requirements could make court trials longer because the systems of the court are not suited to the cases or the resources are not available in the court. This brings a need to create special courts that are equipped to address peculiar crime cases in a more effective and faster model. These courts are better poised to address the peculiarities of special cases and pass better faster judgments. In Abakaliki and Afipko prisons, many inmates await trials on cases that have taken years to be processed by regular courts but could have taken significantly lesser time to be processed by special courts. The repercussion of this gap is that the awaiting-trial inmates crowd prison facilities and generate the challenges of overcrowding currently experienced in Nigerian prisons. A good sample is domestic crimes, issues of marriage could be tried in special courts that address domestic affairs. Such court would have the empathy, experience, and demeanor to judge domestic issues in faster, more intuitive manners - and would eventually address domestic cases significantly faster than regular courts that lack the empathy, understanding and intuitions on domestic affairs. This is also applicable to drugaddiction-related crimes where processes of regular courts may lack the capacity to quickly and fully address such cases. A special court with experience and empathy in managing addiction cases would more efficiently process addiction-related crime than regular courts without such experience. Therefore, special courts were found very necessary to enhance quick dispensation of justice. As such, courts will be efficient in justice delivery and enhance better information sharing.

\section{REFERENCES}

Abdulkarim, Y. (2012). An analysis of socio-economic impact of imprisonment in Nigeria. Developing Country Studies, 2 (9), 148-155.

Adegbami, A., \& Uche, C. I. N. (2015). Good governance and prison congestion in Nigeria: the case of maximum security prison llesa. Public Policy and Administration Review, 3 (2), 27-3. https://doi.org/10.15640/ppar.v3n2a3

Agbesi, E. K. (2016). Causes and effects of overcrowding at prisons: a study at the Ho Central prison, Ghana. Public Policy and Administration Research, 6 (5), 1-11.

Agbonika, J., \& Alewo, M. (2014). Delay in the administration of criminal justice in Nigeria: issues from a Nigerian viewpoint. Journal of Law, Policy and Globalization, 26, 130- 138.

Ajah, B. O, Uwakwe, E. E., Nwokeoma, B. N., Ugwuoke C. O., \& Nnnamani, R. G. (2020). Ameliorating the plight of awaitingtrial inmates in Ebonyi State, Nigeria through reasonable bail condition. Pertanika Jounal of Social Sciences \& Humanities, 28 (4), $2897-2911$. https://doi.org/10.47836/pjssh.28.4.22

Ajah, B. O. (2018). Educational training of inmates in Awka and Abakaliki Prisons, Nigeria Journal International Journal of Criminal Justice Sciences. 13 (2), 299-305

Ajah, B. O., \& Okpa, J. T. (2019). Digitization as a solution to the problem of awaiting-trial inmates in Ebonyi State, Nigeria. International Journal of Criminal Justice Sciences, 14 (2), 199-207.

Ajah, B. O., \& Ugwuoke, C. O. (2018). Juvenile Justice Administration and Child Prisoners in Nigeria. International Journal of Criminal Justice Sciences, 13 (2), 438-446.

Ajah, B.O., Ajah, A.I., \& Obasi, C. O. (2020). Application of Virtual Reality (VR) and Augmented Reality (AR) in the Investigation and Trial of Herdsmen Terrorism in Nigeria. International Journal of Criminal Justice Sciences, 15 (1), 1-20.

Ajah, B.O., Dinne, C.E., \& Salami, K. K. (2020). Terrorism in Contemporary Nigerian Society: Conquest of Boko-Haram, Myth or Reality. International Journal of Criminal Justice Sciences, 15 (1), 312-324.

Ajah, O. B., \& Onyejegbu, D. C. (2019). Neo-Economy and Militating Effects of Africa's Profile on Cybercrime. International Journal of Cyber Criminology, 13 (2), 326-342.

Akinseye, Y.G. (2009). Nigerian Prisons: Justice Sector Reform and Human Rights in Nigeria. Abuja: CSLS Publishing.

Alemika, E. E. O., \& Alemika, E. I. (2005). Penal policy: prison conditions and prisoners' rights in Nigeria. In Bem Angwe, B and Dakas, C J (ed) 2005. Readings in human rights. Lagos: Graphic. 
Amnesty 2008. International (2008). Nigeria: prisoners rights systematically flouted. Amnesty International, AI Index: AFR $44 / 001 /$ https://doi.org/10.1007/978-1-349-74027-7 28

Anthony, E.O., Obasi, C.O., Obi, D.O., Ajah, B.O., Okpan, O.S., Onyejegbu, C.D., Obiwulu, A. C., \& Onwuama, E. M. (2021). Exploring the reasons for perennial attacks on churches in Nigeria through the victims' perspective. HTS Teologiese Studies/Theological Studies, 77(1), a6207. https://doi.org/10.4102/hts.v77i1.6207

Araromi, M. A. (2015). Prisoners' rights under the Nigerian law: legal pathways to progressive realization and protection. Journal of Sustainable Development, Law \& Policy, 6 (1), 170-198. https://doi.org/10.4314/jsdlp.v6i1.8

Areh, C. E., Onwuama, E. M., \& Ajah, B. O. (2020). Social consequences of wife-battering in Ogbaru and Onitsha north local government areas of Anambra State, Nigeria. FWU Journal of Social Sciences, 14 (4), 80-92. https://doi.org/10.51709/FW12727

Ayade, A. E. (2010). Problems of prison overcrowding in Nigeria: Some lessons from South Africa and America. A dissertation submitted to Legal Studies Department, Central European University, Hungary.

Barchue, A. W. (2012). Pre-trial detention and the rule of law in Nigeria and Liberia. A Research Dissertation Submitted to Loyola University Chicago School of Law Rule of Law for Development John Felice Center, Rome.

Chukwujindu, M.O., Akintude, A. A., \& Alaba, I. K. (2016). Restorative Justice and Non- Custodial Measures: Panacea to Recidivism and Prison Congestion in Nigeria. NAUJILJ.

David G.M. (2017). Curbing delays in the administration of justice: case management in the magistrate courts. A paper presented by Justice David G. Mann at the orientation course for newly appointed magistrates, on 24th July 2017.

Ebonyi State Judicial Record (2018). Official Gazette of Ebonyi State Judiciary.

Emeka, J.O., Achu, A. A., Dien, U. U., \& Uyang, F. (2016). Awaiting trial among suspected criminal persons and lack of legal representation in Cross River State- Nigeria. International Journal of Sociology and Anthropology Research, 2 (1), 1-6.

Emmanuel, S. P. A. St. (2016). Service work as an antidote to prison problems in Nigeria. AGORA International Journal of Juridical Science, 1, 29-39.

Eze, O. J., Obi, D. O., \& Ajah, B. O. (2020). Nigerian criminal justice system and victims of crime neglect in Enugu Urban. FWU Journal of Social Sciences, 14 (3), 41-53. https://doi.org/10.51709/FW1272J/fall2020/4

Eze, O.J., Ajah, B.O., Nwonovo, O. S., \& Atama, C.S. (2021).Health sector corruption and COVID-19 outbreak: evidence from Anambra and Enugu States, Nigeria. Journal of Contemporary African Studies. https://doi.org/10.1080/02589001.2021.1921129

Halima, D. (2016). Enhancing justice administration in Nigeria through information and communications technology. Marshal Journal of Information Technology and Privacy Law, $32(2)$.

Ibe, S. (2016). Expanding access to justice for victims of pretrial injustice: reflections on the decision in Sikiru Alade V Nigeria. The Pan-African Yearbook of Law, II.
Inyang, J. D., \& Awakessien, M. S. (2014). An investigation on the application of criminal justice procedure and its impact on crime factors in Akwa Ibom State, Nigeria. International Journal of Humanities and Social Science, 4 (9), 214-224.

Nigerian Police Record (2018). Official Gazette of the Nigeria Police.

Nigerian Prison Service Record (2017). Official Gazette of the Nigeria Prisons.

Nnam, M. U., Ajah, B. O., Arua, C. C., Okechukwu, G., \& Okorie, C. O. (2019). The War must be Sustained: An Integrated Theoretical Perspective of the Cyberspace-Boko Haram Terrorism Nexus in Nigeria. International Journal of Cyber Criminology, 13 (2), 379- 395. https://doi.org/10.1007/s12144-021-01680-0

Nnam, M.U., Effiong, J.E., Iloma, D.O., Terfa, I.M., \& Ajah, B.O. (2021) Hazardous drinking and the dark triad: an antidote for manipulative behaviour among students. Current Psychology, 40(4), 1-7.

Nnamani, G.R., Ilo, K.O., Onyejegbu, D. C., Ajah, B.O., Onwuama M. E., Obiwulu, A. C., \& Nzeakor, O. F. (2021). Use of Noncustodial Measure and Independent Monitoring Body as Panacea to Awaiting-Trial Problems in Ebonyi State, Nigeria. International Journal of Criminal Justice Sciences, 16 (1), 5163

Nnochiri, I. (2011, July 28). Criminal justice system in Nigeria obsolete. Vanguard. Retrieved from https://www.vanguardngr.com/2011/07/criminal-justicesystem-in-nigeria- obsolete-says-nba/

Nweke, J. O. (2015). Assessment of the willingness of Ebonyi state government to adopt the contributory pension scheme in Nigeria. Canadian Social Science, 11 (3), 3441.

Okunola, R.A., \& Dinne, C.E. (2016). Factors underlying utilization of legal aid scheme by awaiting trial inmates in Agodi prison Ibadan, Oyo State, The Nigerian Journal of Sociology and Anthropology, 14 (1), 129-143. https://doi.org/10.36108/NJSA/6102/14(0180)

Olusegun, A. J. (2012). Nigeria prisons and the dispensation of justice. International Journal of Arts and Humanities, 1 (3), 208-233.

Omaka, A. C. (2010). Decongesting prisons in nigeria: the EBSU law clinical model. International Journal of Clinical Legal Education, 533-562.

Omale, D. J. O (2013). Riots/jail breaks in nigeria prisons: an aetiological study. Canadian Social Science, 9 (1), 158-164.

Opafunso, Z. O., \& Adepoju, O. O. (2016). Prison reforms system and inmate $s$ welfare in Nigeria. Arts and Social Sciences Journal, 7 (1), 1-6.

Ugwuoke, C. O., Ajah, B. O., \& Onyejegbu, C. D. (2020). Developing patterns of violent crimes in Nigerian democratic transitions. Aggression and Violent Behavior, 53, 1-8. https://doi.org/10.1016/j.avb.2020.101457

Ugwuoke, C. U. (2010). Criminology: explaining crime in the Nigerian context. Nsukka: Great AP Express Publishers Ltd.

Ukwayi, J. K., \& Okpa, J. T. (2017). Critical assessment of Nigeria criminal justice system and the perennial problem of awaiting trial in Port Harcourt maximum prison, Rivers State. Global Journal of Social Sciences, 16, 17-25. https://doi.org/10.4314/gjss.v16i1.3

\section{https://doi.org/10.6000/1929-4409.2021.10.136}

(C) 2021 Onyejegbu et al.; Licensee Lifescience Global.

This is an open access article licensed under the terms of the Creative Commons Attribution Non-Commercial License (http://creativecommons.org/licenses/by-nc/3.0/) which permits unrestricted, non-commercial use, distribution and reproduction in any medium, provided the work is properly cited. 